\title{
Mapping of health innovations in response to the COVID-19 pandemic in Eastern Mediterranean and selected Arab Countries
}

Ahmed Mandil, ${ }^{1}$ Ruth Mabry, ${ }^{2}$ Barbara Milani, ${ }^{3}$ Mohamed Nour, ${ }^{1}$ Mohamed Afifi ${ }^{4}$ and Karim Abdel-Ghani ${ }^{5}$

${ }^{1}$ Coordinator, Research and Innovation, World Health Organization Regional Office for the Eastern Mediterranean, Cairo, Egypt ${ }^{2}$ Independent Public Health Researcher, Muscat, Oman. ${ }^{3}$ Independent Public Health Consultant, France. ${ }^{4}$ Arab States Regional Office, United Nations Populations Fund, Cairo, Egypt; ${ }^{\mathrm{A}} \mathrm{Arab}$ States Regional Office, International Communications Union, Cairo, Egypt. (Correspondence to: Ahmed Mandil: mandila@who.int)

\begin{abstract}
Background: COVID-19 is the first pandemic during which innovative technologies are being used to keep people connected, safe, and productive while being physically and socially apart.

Aims: This study aimed to map health innovations in response to the pandemic in the Eastern Mediterranean Region.

Methods: Health innovations are defined as novel methods, models, processes, products, services, or a combination that produce notable public health impact in people, families, and communities at large. We used two approaches: an online survey using a specially designed data collection tool and a review of publicly available literature using PubMed, IMEMR, Google Scholar, Google, and INSERM search engines. Data collection was conducted between September 2020 and February 2021.

Results: We describe 80 innovations in this region, of which 13 were identified through the online survey and 76 via literature review. For the purposes of this paper, we subclassified two-thirds of these innovations $(\mathrm{n}=52 ; 65 \%)$ as "digital health innovations", including telehealth and telemedicine, surveillance, and contact tracing. The rest were classified as "non-digital health innovations", including prevention and clinical management.

Conclusion: This mapping exercise provides baseline information on response to the pandemic by the public and private sectors, innovation hubs within and outside the region, as well as by entrepreneurs and innovators. In-depth studies measuring the impact of health innovations will likely only become available when the pandemic is under better control and experts are able to assess the replicability, sustainability and scalability of the health innovations introduced.

Keywords: Global, action plan, health, innovation, mapping, Eastern Mediterranean, pandemic

Citation: Mandil A; Mabry R; Milani B; Nour M; Afifi M; Abdel-Ghani K. Mapping of health innovations in response to the COVID-19 pandemic in Eastern Mediterranean and selected Arab Countries. East Mediterr Health J. 2022;28(2):130-143. https://doi.org/10.26719/emhj.22.028

Received: 25/07/21; accepted: 06/12/21

Copyright (C) World Health Organization (WHO) 2022. Open Access. Some rights reserved. This work is available under the CC BY-NC-SA 3.0 IGO license (https://creativecommons.org/licenses/by-nc-sa/3.o/igo)
\end{abstract}

\section{Introduction}

Promoting health innovations is one of seven accelerator themes in the Global Action Plan for healthy lives and wellbeing (GAP). Signed by 12 international health and development agencies, the plan aims to support countries in accelerating progress on the health-related Sustainable Development Goals (SDGs) (9), which forms the framework of action for the recently launched "Regional Health Alliance" of 12 regional health partners (10). Mapping health innovations was identified as a key area of joint collaboration by the research, development, access and innovation working group comprising seven UN agencies (UNAIDS, UNDP, UNESCO, UNFPA, UN Women, ITU, and WHO).

COVID-19 is the first pandemic in human history during which innovative digital technologies are being used at unprecedented scales to keep people connected, safe, and productive while being physically and socially apart (1-4). Innovations are being used to support population surveillance, case identification, contact tracing, risk communication, and clinical management
(2). Telehealth services are being used by healthcare providers and clients to prevent, diagnose, and treat people at risk of COVID-19; they provide opportunity for continuous care while limiting direct physical contact and thus reducing morbidity and mortality (4).

COVID-19 has impacted the Eastern Mediterranean Region (EMR), a region heavily affected by emergencies and armed conflicts, prior to the current pandemic (5). As in other parts of the world, countries in the region have faced numerous challenges in managing the COVID-19 response including in information sharing, protection of health workers, observation of the public health measures, and ensuring continuity of essential health services. On the other hand, there are emerging examples of how health innovations, such as telemedicine, mobile applications and social media have been critical for achieving positive health outcomes in countries of the Region $(4,6-8)$. This study aimed to map health innovations in response to the pandemic in EMR, as a joint activity of the research, development, access and innovation working group. 


\section{Methods}

For this mapping exercise, health innovations were defined as "novel methods, models, processes, products, services, or a combination that produce public health impact in people, families, and communities at large". Novel refers to a new method, approach or process, or an upscaling of existing platforms and processes. Digital health innovations refer to processes, products or services that use online platforms, websites and/or mobile applications. All other innovations were classified as non-digital. Given the variation in geographic coverage of the different UN agencies, the survey included all 22 countries of the EMR plus three Arab countries (Algeria, Comoros Islands, Mauritania) to ensure that the study covers both the Arab world and the EMR. Two approaches were used: an online survey and a review of publicly available literature.

\section{Online Survey}

A specially designed data collection tool was developed and reviewed by the working group. The tool was structured around 10 key areas of health innovation: education, community engagement and communication, workforce development and economic support, prevention, detection and testing, emergency communication, management, vulnerable groups, data platforms, and policy and practice. For each innovation, respondents were requested to provide summary information, stage of development (conceptualization, research and development, evidence-based effectiveness, upscaling and sustainability), links to background documentation, and contact details.

All co-authors disseminated an invitation to complete the online survey through agency-specific networks at the country and regional levels including the Public Health in the Arab World Discussion group. The survey was available online during September 2020 and remained open for response through December 2020. All authors and acknowledged contributors disseminated information about the survey through their own national/regional networks, including sharing on the listserv of the Public Health in the Arab World (PHAW) to ensure wide coverage. Data collected was reviewed and respondents were contacted by email/phone to obtain additional information, if required.

\section{Online literature review}

In parallel to the online survey and using the search terms "COVID" and "innovation" and countries in the EMR/Arab region, a web-based review of publicly accessible literature was conducted between November 2020 and February 2021, to search for health innovations within the COVID-19 context. The search engines used included: Index Medicus for the Eastern Mediterranean Region (IMEMR), PubMed, Google scholar, Google, INSERM (for French speaking countries of the region), and ADELF (Association of French-Speaking Epidemiologists). The mapping process was iterative with the increase in familiarity of the COVID-19 health innovations in the region.
Data was extracted and collated thematically according to the most common innovations reported, to facilitate synthesisation of information into a descriptive summary. Whenever feasible, innovators were contacted to obtain additional information. This mapping exercise did not cover vaccines, diagnostics and therapeutics linked to the COVID-19 prevention and control, or clinical practice guidelines because specific WHO teams are investigating these types of innovations or guidelines.

\section{Results}

Although over 220 people accessed the online survey, only 31 respondents provided detailed information (September-December 2020). After eliminating partial completion and duplicate files, 29 responses from 13 countries (Algeria, Bahrain, Egypt, Iran, Lebanon, Libya, Jordan, Mauritania, Palestine, Qatar, Saudi Arabia, Sudan, and United Arab Emirates) provided sufficient information covering the 13 innovations identified, including links and/or email addresses for additional information from respondents.

The web search obtained over 200 published articles, press releases, weblinks, and webpages on innovations conceived and/or used in one or more of the 25 countries in response to the COVID-19 pandemic. Seventy-six innovations were identified across all countries of the EMR and the three Arab countries that are not part of EMR (Algeria, Comoros and Mauritania). Nine of these were already identified through the online survey based on similarities in names and descriptions (see asterisks in Tables 1-4).

This paper describes 80 innovations identified through the two-step data collection process. We subclassified two-thirds of these $(n=52 ; 65 \%)$, including telehealth and telemedicine, surveillance, and contract tracing, as "digital health innovations" because they all used online platforms, websites and/or mobile applications (Tables 1-3). The remaining were classified as "non-digital health innovations", including prevention and clinical management (Table 4). Of the 10 key areas of innovations described in the methods and online survey, all innovations came under at least one of these classifications except for policy and practice.

\section{Telehealth and telemedicine}

Nearly half ( $n=35,44 \%$ ) of identified innovations were related to patient management, telehealth, telemedicine and digital communication, and were used for COVID-19 pandemic response in 17 of the 25 target countries (Table 1). The platforms included websites, smartphones and mobile applications and were available in one or more of the national language(s) including Arabic, English, French, and Urdu. The COVID-19 web-pages linked to the Saudi Arabia Ministry of Health website also had information in Hindi, Indonesian, and Tagalog (among other languages) to facilitate communication with the non-national populations residing in the country. 


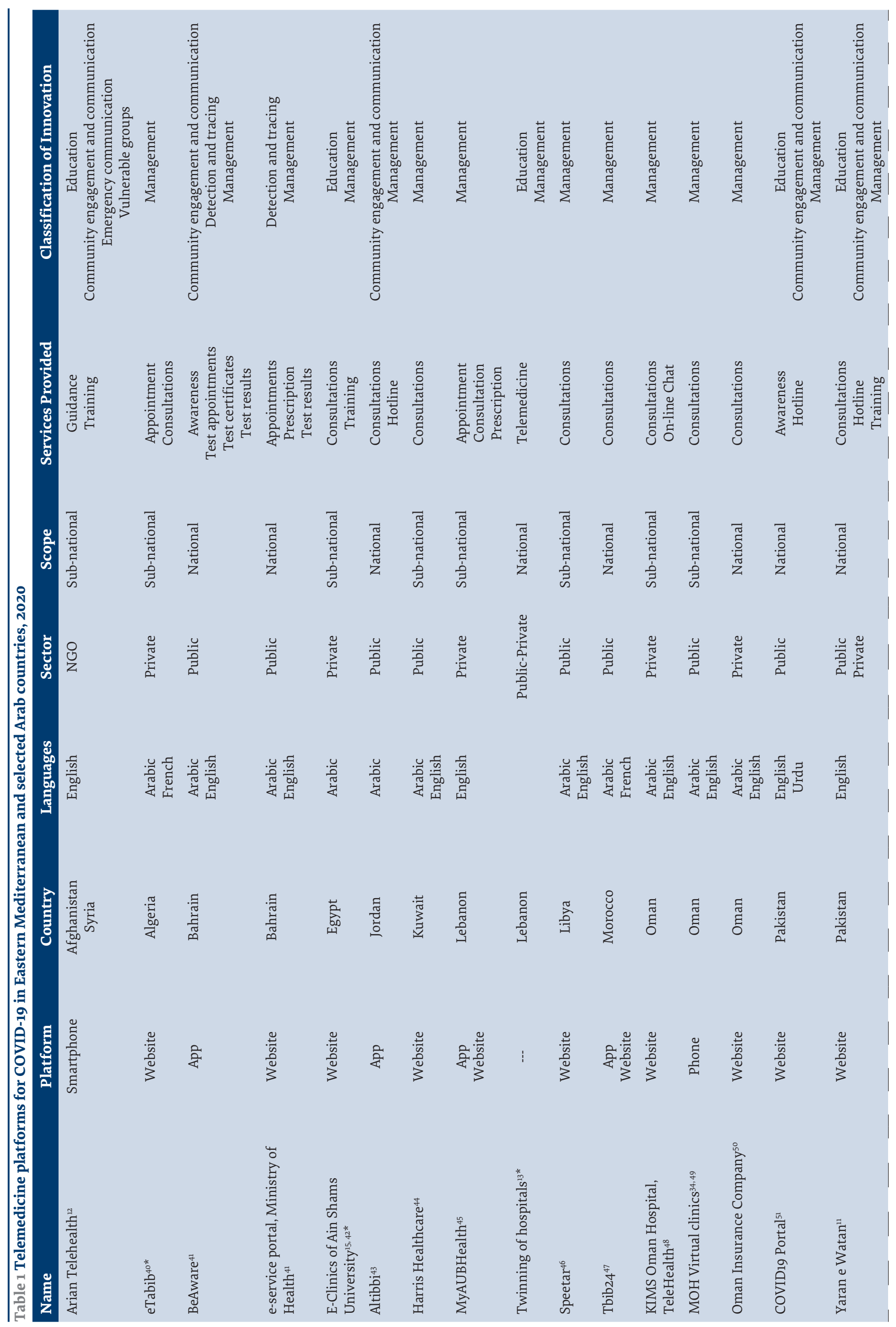




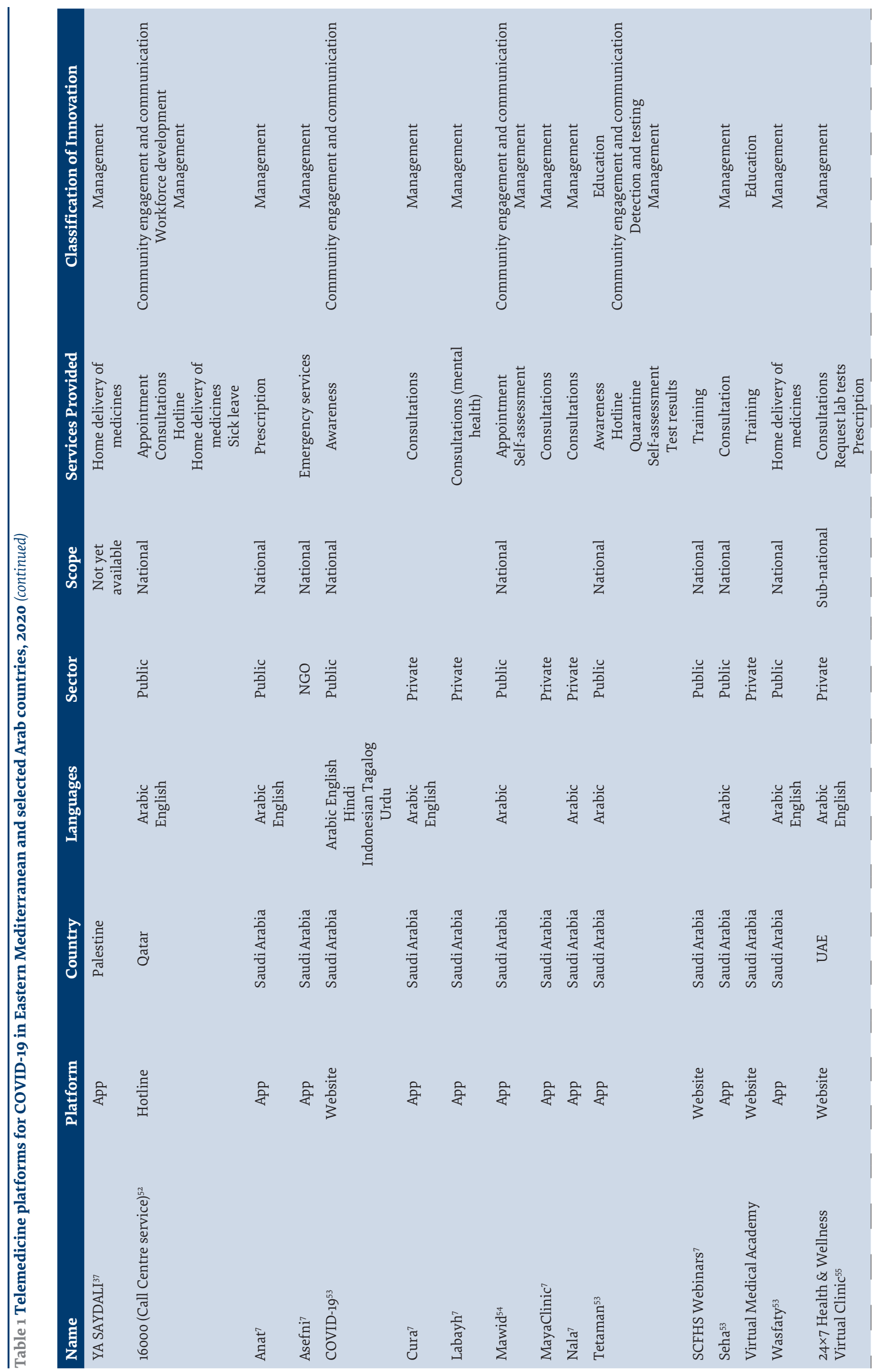




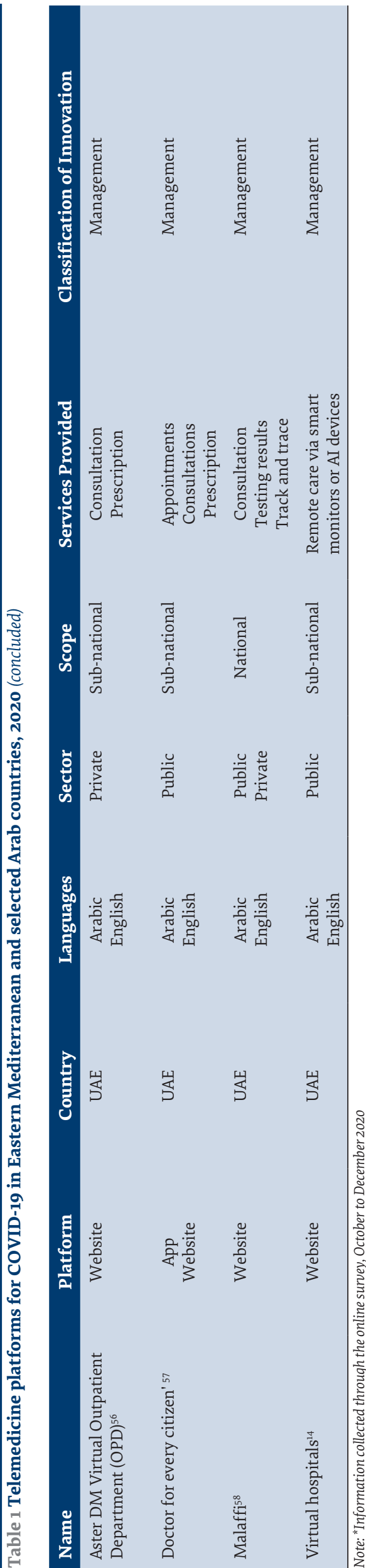

Slightly more than half of the telemedicine services $(n=19 ; 54 \%)$ were developed by the public sector, including 16 at the national level. COVID-19-related services provided included awareness-raising, appointments reservation including for PCR testing, healthcare consultations, online chats or hotlines, prescriptions, and home delivery of medications.

Two applications, Arian Teleheal (in Afghanistan and Syria) and Yaran e Watan (in Pakistan) (11,12), provided guidance and training for health professionals. Telemedicine was established in Lebanon through partnerships by public and private healthcare institutions to train and exchange information such as management and treatment protocols between health professionals (13). Egypt and the United Arab Emirates are developing virtual hospitals; efforts which began prior to the pandemic but became a high priority during the pandemic (14-15).

\section{Digital platforms for surveillance}

Digital platforms for COVID-19 surveillance were available in 18 countries and used to communicate trends publicly. At least nine countries (Comoros Islands, Iraq, Lebanon, Libya, Mauritania, Palestine, Somalia, Sudan, and Syria) reported upscaling DHIS2 and eWARN surveillance platforms for their surveillance dashboards, as part of their response to the COVID-19 pandemic. In addition to communicating the number of officially detected COVID-19 cases in the country, some platforms provided more comprehensive information and evidence on how countries were able to manage, analyse, interpret, and publicly communicate national trends.

Five countries (Afghanistan, Algeria, Djibouti, Libya, and Yemen) used their platforms to monitor the pandemic but did not make them publicly accessible (16). At least nine countries (Bahrain, Egypt, Jordan, Kuwait, Morocco, Oman, Pakistan, Tunisia and UAE) possibly upscaled their surveillance platforms, including institutional websites or mobile applications, to monitor the COVID-19 epidemiology. Ten countries provided data at the subnational level, including Comoros Islands, Iraq, Jordan, Lebanon, Mauritania, Oman, Pakistan, Palestine, Somalia, and Sudan.

\section{Contact tracing, detection and testing}

Fifteen contact tracing applications were observed to have been developed in a range of public sector fields, including education, health and interior and used in 14 countries (Algeria, Bahrain, Egypt, Iran, Jordan, Kuwait, Lebanon, Morocco, Oman, Pakistan, Qatar, Saudi Arabia, Tunisia, and UAE). Majority of identified mobile applications were bilingual, providing information in Arabic and English/French. They included a system to notify users if they had been in contact with someone with COVID-19 and/or a person in quarantine.

\section{Other Innovations}

Twelve non-digital innovations and four innovative processes and approaches were reported. Of the 12 non-digital innovations, four were infection prevention and control (IPC) devices and eight were clinical management devices, including five ventilators and two oxygen solutions. Three each were from Palestine and Somalia, two each from Algeria and Morocco and one each from Jordan and Lebanon.

The IPC devices included two disinfection cabins or passthroughs for entrance to buildings (17-19), and one was a multi-use device that could measure temperature, eject sanitizers and disinfect body and feet (20). All these innovations were developed with local 


\begin{tabular}{|c|c|c|c|c|c|}
\hline Name & Country & Language & Managed by & $\begin{array}{c}\text { Scope or } \\
\text { Disaggregation }\end{array}$ & Publicly available real-time dashboard \\
\hline MoH website & Bahrain & $\begin{array}{l}\text { Arabic } \\
\text { English }\end{array}$ & $\mathrm{MoH}$ & National & https://healthalert.gov.bh/en/ \\
\hline MoH website & Comoros & French & $\mathrm{MoH}$ & Sub-national & https://stopcoronavirus.km/ \\
\hline Egyptcare & Egypt & Arabic & $\begin{array}{l}\text { Government of } \\
\text { Egypt }\end{array}$ & National & $\begin{array}{l}\text { https://www.care.gov.eg/EgyptCare/Index.aspx } \\
\text { https://play.google.com/store/apps/details?id=com. } \\
\text { IDSC.EgyCare }\end{array}$ \\
\hline EWARN 59 & Iraq & English & WHO / MoH & Sub-national/sex & $\begin{array}{l}\text { https://app.powerbi.com/w?r=eyJrIjoiNjljMDhiYmItz } \\
\text { ThMSooMDlhLTg3MjItMDNmM2FhNzE5NmM4Ii } \\
\text { widCI6ImY2MTBjMGI3LWJkMjQtNGIzOSo4MTBiL } \\
\text { TNkYzI4MGFmYjU5MCIsImMiOjh9 }\end{array}$ \\
\hline MoH website & Jordan & $\begin{array}{l}\text { Arabic } \\
\text { English }\end{array}$ & $\mathrm{MoH}$ & Sub-national & $\begin{array}{l}\text { https://corona.moh.gov.jo/ar } \\
\text { https://corona.moh.gov.jo/en }\end{array}$ \\
\hline MoH website & Kuwait & $\begin{array}{c}\text { Arabic } \\
\text { English }\end{array}$ & $\mathrm{MoH}$ & National & https://corona.e.gov.kw/en \\
\hline DHIS2* $^{*}$ & Lebanon & English & $\mathrm{MoH}$ & Sub-national & $\begin{array}{l}\text { http://drm.pcm.gov.lb/Programs/Be-Informed/\%D9\% } \\
\text { 81\%D9\%8A\%D8\%B1\%D9\%88\%D8\%B3-\%D8\%A7\%D9\%84 } \\
\text { \%D9\%83\%D9\%88\%D8\%B1\%D9\%88\%D9\%86\%D8\%A7/\% } \\
\text { D8\%A7\%D9\%84\%D9\%85\%D9\%86\%D8\%B5\%D8\%A7\%D8 } \\
\text { \%AA-\%D8\%A7\%D9\%84\%D8\%A7\%D9\%84\%D9\%83\%D8\% } \\
\text { AA\%D8\%B1\%D9\%88\%D9\%86\%D9\%8A\%D8\%A9 }\end{array}$ \\
\hline EWARN $^{31} \#$ & Libya & English & WHO / MoH & National & $\begin{array}{l}\text { https://reliefweb.int/report/libya/libya-health-sector- } \\
\text { bulletin-december-2020 }\end{array}$ \\
\hline DHIS2\# & Mauritania & English & $\mathrm{MoH}$ & Sub-national & https://www.sante.gov.mr/?cat=4 \\
\hline MoH website & Morocco & English & $\mathrm{MoH}$ & National & $\begin{array}{l}\text { http://www.covidmaroc.ma/Pages/Accueilfr.aspx } \\
\text { http://www.covidmaroc.ma/Pages/LESINFOAR.aspx }\end{array}$ \\
\hline Tarassud Plus ${ }^{60}$ & Oman & $\begin{array}{l}\text { Arabic } \\
\text { Bengali } \\
\text { English } \\
\text { Hindi } \\
\text { Urdu }\end{array}$ & $\mathrm{MoH}$ & Sub-national & $\begin{array}{l}\text { https://tarassud.moh.gov.om/\#/login } \\
\text { https://play.google.com/store/apps/details?id=om. } \\
\text { gov.moh.tarassudapplication\&hl=en }\end{array}$ \\
\hline COVID Portal & Pakistan & English & $\mathrm{MoH}$ & Sub-national & https://covid.gov.pk/stats/pakistan \\
\hline DHIS2 & Palestine & English & $\begin{array}{c}\text { National } \\
\text { Institute of } \\
\text { Public Health }\end{array}$ & & https://corona.ps/details \\
\hline DHIS2 & Somalia & English & WHO & Sub-national & $\begin{array}{l}\text { https://bmgf.maps.arcgis.com/apps/opsdashboard/ } \\
\text { index.html\#/dod9a939c5fa401caa3a7447e72b2017 }\end{array}$ \\
\hline DHIS2 $^{16 *}$ & Sudan & English & $\mathrm{MoH}$ & Sub-national & http://sho.gov.sd/corona/ \\
\hline EWARN $^{31} \#$ & Syria & $\begin{array}{l}\text { Arabic } \\
\text { English } \\
\text { Turkey }\end{array}$ & WHO / MoH & National & $\begin{array}{l}\text { https://www.acu-sy.org/en/early-warning-alert-and- } \\
\text { response-network/ }\end{array}$ \\
\hline MoH website & Tunisia & $\begin{array}{l}\text { Arabic } \\
\text { English } \\
\text { French }\end{array}$ & $\mathrm{MoH}$ & National & https://www.onmne.tn/en/category/covid-19/ \\
\hline $\begin{array}{l}\text { Government } \\
\text { website }\end{array}$ & UAE & $\begin{array}{l}\text { Arabic } \\
\text { English }\end{array}$ & $\begin{array}{l}\text { National } \\
\text { Emergency } \\
\text { Crisis and } \\
\text { Disasters } \\
\text { Management } \\
\text { Authority }\end{array}$ & National & https://covidı9.ncema.gov.ae/en \\
\hline
\end{tabular}

expertise, except for the OxyGEN ventilator, which was designed in Spain and was being tested in Jordan and other countries (21). The adapted snorkelling mask was designed in Italy and was under approval in Lebanon (22); the solar-powered oxygen concentrator was designed in Canada and was being piloted/used in Somalia (23).

Five innovations were designed by groups of individuals within national academic institutions
$(18,24,25)$ or in collaboration with other national or international institutions and the private sector $(17,26)$. Two others were designed by local entrepreneurs, including the Creators of Innovation's Machine, a device designed by a local business that manages entry at workplaces (ejecting hand sanitizer, measuring temperatures, spraying disinfectant) and is currently being used in various settings in Gaza, Palestine (20) 


\begin{tabular}{|c|c|c|c|c|}
\hline Name & Country & Language & Managed by & $\operatorname{Link}(s)^{@}$ \\
\hline Coronavirus Algérie ${ }^{61}$ & Algeria & Arabic & $\begin{array}{l}\text { Ministry of Micro- } \\
\text { Enterprise, Startup and } \\
\text { Economy of Knowledge }\end{array}$ & $\begin{array}{l}\text { https://play.google.com/store/apps/details?id=com. } \\
\text { covid19_algeria }\end{array}$ \\
\hline BeAware & Bahrain & $\begin{array}{l}\text { Arabic } \\
\text { English Urdu, } \\
\text { Hindi, Bengali } \\
\text { and Persian }\end{array}$ & $\begin{array}{l}\text { e-Governement Apps } \\
\text { stores }\end{array}$ & $\begin{array}{l}\text { https://apps.bahrain.bh/CMSWebApplication/action/ } \\
\text { howAppDetailsAction?selectedAppID } \\
\text { =321\&appLanguage=en }\end{array}$ \\
\hline Egyptcare & Egypt & Arabic & $\mathrm{MoH}$ & $\begin{array}{l}\text { https://apps.apple.com/eg/ } \\
\text { app/\%D8\%B5\%D8\%AD\%D8\%A9- } \\
\text { \%D9\%85\%D8\%B5\%D8\%B1/id1506794318?|s=1 } \\
\text { https://play.google.com/store/apps/details?id=com. } \\
\text { IDSC.EgyCare }\end{array}$ \\
\hline Mask & Iran & Farsi & $\begin{array}{l}\text { Ministry of Health and } \\
\text { Medical Education }\end{array}$ & https://www.mask.ir \\
\hline $\operatorname{Aman}^{62 *}$ & Jordan & $\begin{array}{l}\text { Arabic } \\
\text { English }\end{array}$ & $\mathrm{MoH}$ & $\begin{array}{l}\text { https://amanapp.jo/ClickCounter/ } \\
\text { Goto?linkType=android\&language=en } \\
\text { https://amanapp.jo/ClickCounter/ } \\
\text { Goto?linkType=apple\&language=en }\end{array}$ \\
\hline Shlonik & Kuwait & $\begin{array}{l}\text { Arabic } \\
\text { English }\end{array}$ & $\begin{array}{l}\text { Central Agency for } \\
\text { Information Technology }\end{array}$ & $\begin{array}{l}\text { https://play.google.com/store/apps/details?id=com. } \\
\text { healthcarekw.app\&hl=en_US\&gl=US }\end{array}$ \\
\hline Maзan ${ }^{63 *}$ & Lebanon & $\begin{array}{l}\text { Arabic } \\
\text { English }\end{array}$ & $\mathrm{MoH}$ & $\begin{array}{l}\text { https://bit.ly/3bh9h0J } \\
\text { https://apple.co/2QJbuJ6 }\end{array}$ \\
\hline Wiqaytna & Morocco & $\begin{array}{l}\text { Arabic } \\
\text { French }\end{array}$ & $\mathrm{MoH}$ & https://www.wiqaytna.ma/Default_Fr.aspx \\
\hline Tarassud $+{ }^{60}$ & Oman & $\begin{array}{l}\text { Arabic } \\
\text { English }\end{array}$ & $\mathrm{MoH}$ & $\begin{array}{l}\text { https://play.google.com/store/apps/details?id=om. } \\
\text { gov.moh.tarassudapplication\&hl=en_US\&gl=US } \\
\text { https://apps.apple.com/om/app/tarassud/ } \\
\text { id1502105746 }\end{array}$ \\
\hline COVID-19 & Pakistan & English & National IT Board & $\begin{array}{l}\text { https://play.google.com/store/apps/details?id=com. } \\
\text { govpk.covid19\&hl=en_US\&gl=US https://apps.apple. } \\
\text { com/pk/app/covid-19-gov-pk/id1504847114 }\end{array}$ \\
\hline EHTERAZ & Qatar & $\begin{array}{l}\text { Arabic } \\
\text { English }\end{array}$ & Ministry Of Interior & https://www.acta.gov.qa/en/ehteraz/ \\
\hline Tabaud App & Saudi Arabia & $\begin{array}{l}\text { Arabic } \\
\text { English }\end{array}$ & $\mathrm{MoH}$ & https://tabaud.sdaia.gov.sa/IndexEn \\
\hline Tawakkalna & Saudi Arabia & Arabic & $\mathrm{MoH}$ & $\begin{array}{l}\text { https://covid19awareness.sa/en/apps-for-your- } \\
\text { health-2 }\end{array}$ \\
\hline $\mathrm{E}_{7 \mathrm{mi}}{ }^{64}$ & Tunisia & $\begin{array}{l}\text { Arabic } \\
\text { French }\end{array}$ & $\begin{array}{l}\text { Observatory of Emerging } \\
\text { Diseases }\end{array}$ & https://e7mi.tn/ \\
\hline ALHOSN UAE & UAE & $\begin{array}{l}\text { Arabic } \\
\text { English }\end{array}$ & $\mathrm{MoH}$ & https://www.alhosnapp.ae/en/home/ \\
\hline
\end{tabular}

and a homemade ventilator, which is being used in three hospitals in Somalia (27). These two designs along with the oxygen solutions mentioned earlier are the only innovations reported to be at the implementation stage. Two additional innovations, the $100 \%$ Moroccan $^{26}$ and $\mathrm{Al}$ Quds' University ventilators, ${ }^{24}$ are reported to be at the production stage; while the remaining seem to be design prototypes.

Based on information from the online survey, four innovative processes and approaches were being used to address riskcommunication and communityengagement. Two focused on raising awareness through children's play in Jordan and using existing social media platforms (https://twitter.com/sharjah_health) in Sharjah, United Arab Emirates. Palestine adapted health care policies to sustain management of patients with noncommunicable diseases. The United Nations Development Programme
(UNDP) is developing a WhatsApp application related to community engagement, to assist individuals in estimating their risk of COVID-19 infection. Further details about these initiatives are needed to better understand their usefulness and replicability.

\section{Discussion}

This mapping exercise identified 80 COVID-19 related health innovations conceived and/or used in countries of the Arab World, including the EMR. Two-thirds of the innovations were "digital health innovations", including telehealth and telemedicine, surveillance, and contact tracing, detection, and testing. The digital platforms, websites, smartphones and mobile applications are already in use, with many mobilized at the national level. The "non-digital health innovations" included IPC devic- 


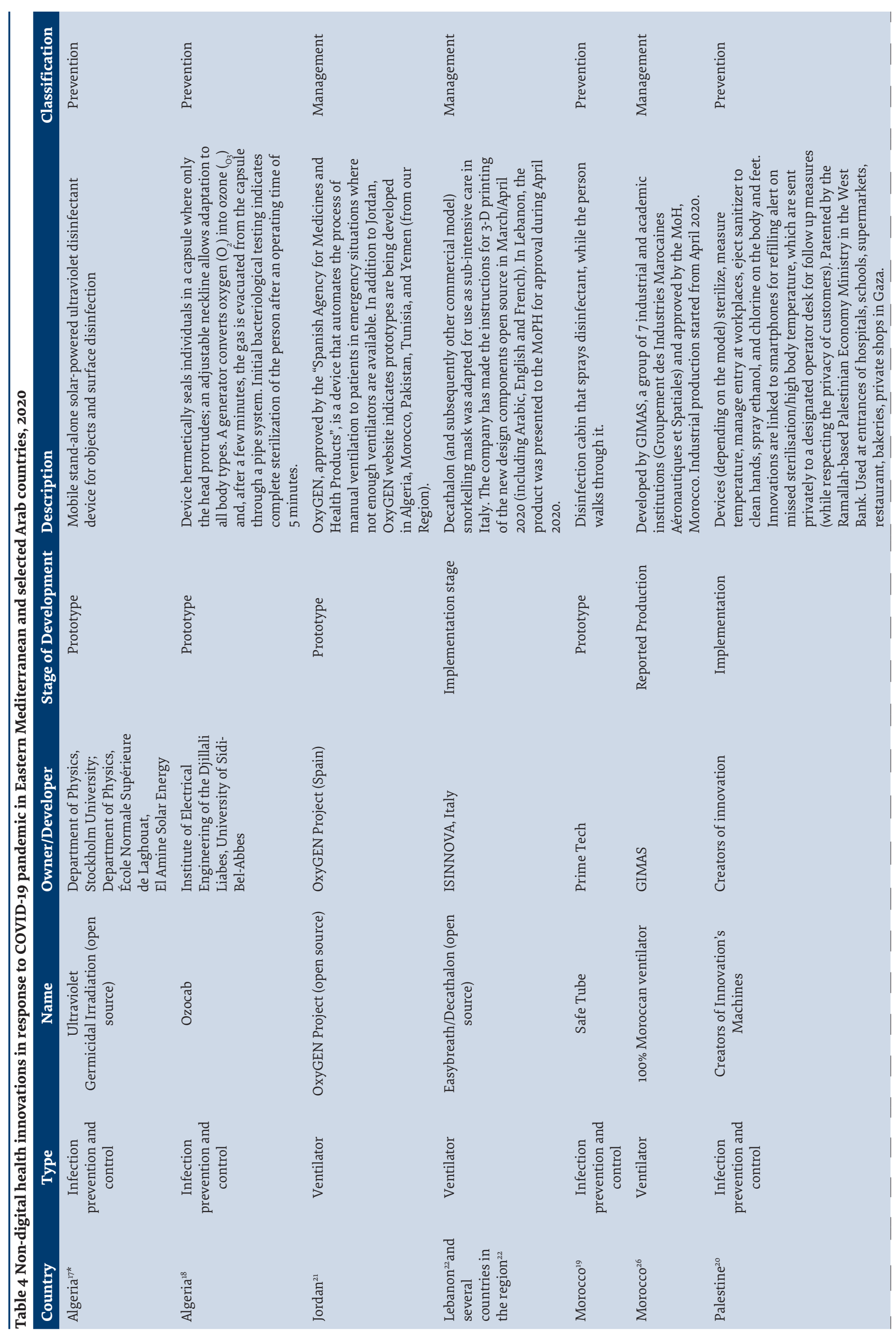




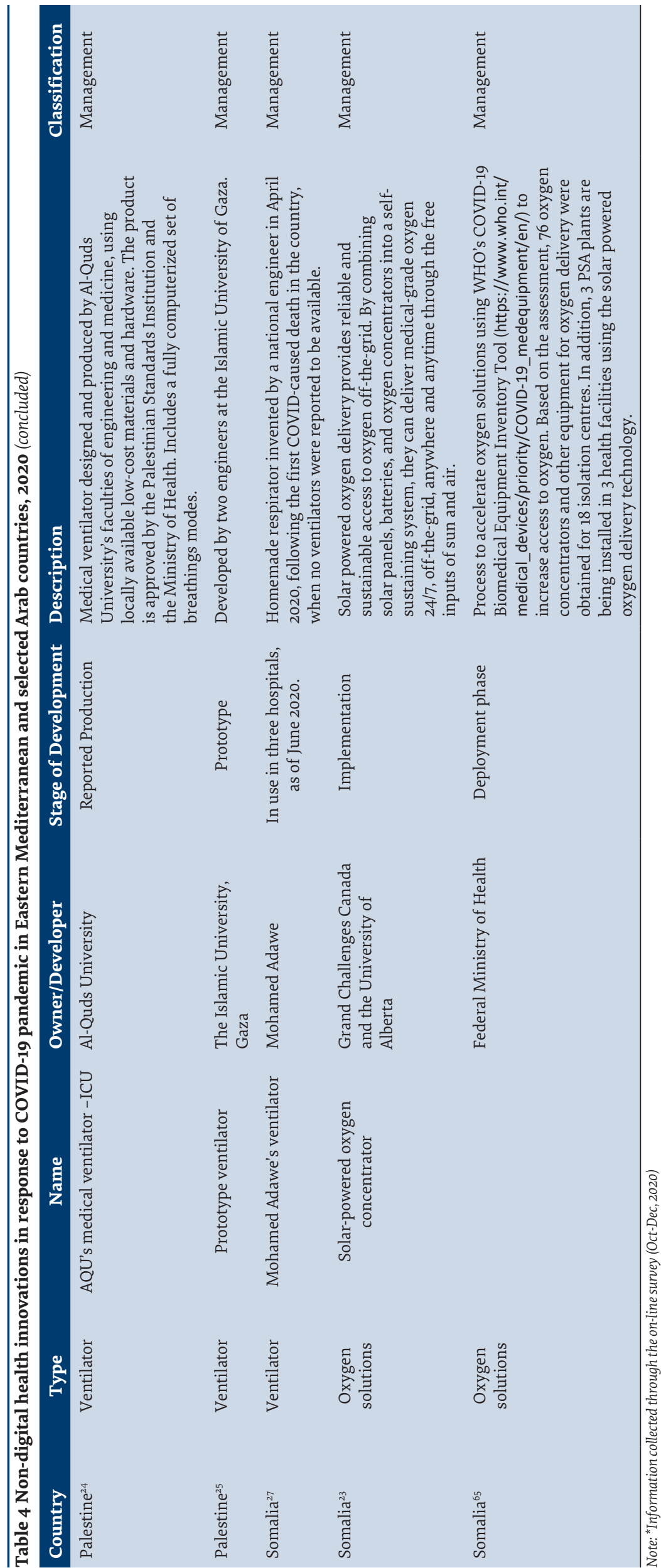

es, ventilators and oxygen generators and a few innovative process and approaches for prevention as well as chronic/noncommunicable disease management.

Two years ago, Braithwaite and colleagues identified five trends shaping the future of health systems: sustainable health systems, genomics revolution, emerging technologies, global demographical dynamics and new models of care (28). The COVID-19 pandemic has impacted key industries driving the adaptation of innovative processes and infrastructure, including within the health system, to address the increasing demand for goods and services and ensure operational efficiency $(2,29)$. The literature review provided numerous examples of innovations, including new technologies and models of healthcare in the Eastern Mediterranean Region.

Digital technology enhanced capacity for real-time data availability so that countries could better monitor the COVID-19 situation whether for testing, diagnosis, or disease trends (2). Digital epidemiological surveillance platforms developed by countries or developed internationally (i.e. DHIS2) or regionally (i.e. eWARN) and adapted by countries, have improved linkages between data sources, increased information transparency through publicly available data dashboards, and supported rapid case identification; together providing the visual tools to guide decisionmakers (30,31). Further assessment of the achievements, best practices, and lessons learned from the use of these products and services could provide guidance on how best countries of the region could improve response to future outbreaks, and hence strengthen health system performance.

Digital innovations facilitate greater access to information by both patients and care providers allowing for more patient-centred care, through teleconsultation and e-delivery of services (28). Evidence is emerging on the potential use of digital health for healthcare services while preventing and containing COVID-19 infection, including in the EMR (4,8,32-34). Telehealth through live video conferencing, phone calls (mobile/ landline) and social media has been shown to facilitate prevention (providing sound information), screening (early detection), diagnosing (recommending 
testing as needed) and managing users/patients during the COVID-19 pandemic (4,8,32-34). In Iran, for example, a social media platform provided faster realtime consultation and teleradiology services (4). The widespread popularity of COVID-19 hotlines led to the development of mobile applications to address the huge demand $(6,7)$.

Although innovations include novel methods, products and services, most innovations identified in this study were the introduction or upscaling of digital applications and platforms. The non-digital applications, though few and limited in implementation, show admirable collaborations across government sectors, academia and industry towards identifying solutions to address gaps in COVID-19 response, including IPC and management protocols. Innovative products such as the OXYgen and Decathalon ventilators, shared through Open Source mechanisms, inspired innovators and entrepreneurs in other countries $(21,22,66)$. The innovation cycle from product design to implementation can take a long time, which may explain why most of the identified health innovations were not reported to be implemented (to our knowledge). Nevertheless, it is unclear if it is the short time, limited financing, regulations, or other factors that are delaying taking them to scale. Some countries in the region are encouraging innovations (7), including in response to COVID-19 (34-37); thus, assessing the replicability, sustainability and scalability of the health innovations introduced would be particularly useful.

Regulations, data protection, security and privacy are central to the successful and inclusive use of digital technologies for health (2). For example, the wide use of digital proximity tracking tools, including in the EMR, can help control the spread of COVID-19; however, it threatens fundamental human rights and liberties (38). There are concerns that the COVID-19 emergency may set a precedent that will remain long after the resolution of the pandemic (2). Although efforts have been made to strengthen legislation (39), data protection and privacy laws provide the legal basis for data processing and restrictions on data use (38).

This study reflects a wide variety of health innovations, digital and non-digital, and it is a good portrayal of response to the pandemic. The innovations may vary from one country to the other, they however collectively reflect the response of the public and private sectors, innovation hubs/companies (within or outside the region), and entrepreneurs/innovators. The range of response covers what we had planned for at the beginning of the exercise, including most of the planned fields for investigation, especially prevention, community engagement and communication, emergency communication, vulnerable groups, data platforms, and policy and practice support. Follow-up on identified products included in this review for their production and implementation would be useful to ascertain facilitators and barriers to their use.

The utility of the digital health innovations identified in this study should be examined further to see how best they can be used to ensure continuity of essential health services during a pandemic, and their integration and institutionalization into the healthcare delivery systems, to provide greater access to and more efficient healthcare services $(8,28)$.

The strength of this mapping exercise of COVID19-related health innovations was in the use of two approaches, an online survey and a literature review. However, the low response rate to the online survey is a major limitation despite efforts to contact respondents for additional information about the innovations submitted. Moreover, we may have missed responses from groups that are not in the target networks and because of the definition used for the innovations. The literature review used six search engines, however, the search did not include grey literature such as clinical guidelines from the region and reports from specialized agencies. It was limited to the English language. It is highly likely that many other innovations have been updated and now being used in the region as this field continues to rapidly expand.

\section{Conclusion}

This mapping exercise of COVID-19 health innovations is probably the first of its kind in this region. The two approaches, online survey and literature review, provided useful information, however, it is highly likely that many other innovations were used in the region. Although we obtained information from a few innovators on the products identified, detailed information on replicability, sustainability and scalability was not readily available. Nevertheless, this study can serve as baseline for further work in this area.

\section{Acknowledgement}

AM drafted the proposal, conceptual framework and data collection form which were reviewed and approved by all authors. BM compiled information from the online survey, contacted respondents and conducted the literature review. RM and AM prepared the manuscript. All authors had full access to the data. All authors reviewed the manuscript and accepted the final version. The corresponding author takes final responsibility for the decision to submit for consideration for publication. The authors thank UNAIDS (Simone Salem), UNDP (Mohamed El-Fateh), and UNESCO (Jana El-Baba) colleagues who are/were members of the Working Group for their support in developing the conceptual framework and promoting the on-line survey through their own networks.

Funding: World Health Organization

Competing interests: None declared. 


\section{Cartographie des innovations en matière de santé dans le cadre de la riposte à la pandémie de COVID-19 dans la Région de la Méditerranée orientale et dans certains pays arabes}

\section{Résumé}

Contexte : La COVID-19 est la première pandémie ayant vu l'utilisation de technologies innovantes pour permettre aux personnes de rester connectées, d'être en sécurité et de continuer à être productives tout en étant physiquement et socialement séparées.

Objectifs : La présente étude avait pour objectif d'établir une cartographie des innovations en matière de santé dans le cadre de la riposte à la pandémie dans la Région de la Méditerranée orientale.

Méthodes: Les innovations en matière de santé sont définies comme des méthodes, des modèles, des processus, des produits ou des services inédits, ou l'association de ces éléments, qui ont un impact notable, en termes de santé publique, sur les personnes, les familles et les communautés au sens large. Nous avons utilisé deux approches : une enquête en ligne par le biais d'un outil de collecte de données spécialement conçu à cet effet et un examen de la littérature accessible au public à l'aide des moteurs de recherche PubMed, IMEMR, Google Scholar, Google et celui de l'INSERM. La collecte des données a été réalisée entre septembre 2020 et février 2021.

Résultats: Nous avons identifié 80 innovations dans cette Région, dont 13 à travers l'enquête en ligne et 76 grâce à l'examen de la littérature. Aux fins du présent article, nous avons sous-classé les deux tiers de ces innovations $(\mathrm{n}=52 ; 65 \%)$ dans la catégorie des «innovations en matière de santé numérique », notamment la télésanté et la télémédecine, la surveillance et la recherche des contacts. Les autres ont été classées dans la catégorie des «innovations en matière de santé non numérique », qui correspond notamment à la prévention et à la prise en charge clinique.

Conclusion: Cet exercice de cartographie fournit des informations de base sur la riposte à la pandémie par les secteurs public et privé, les centres d'innovation à l'intérieur et à l'extérieur de la Région, ainsi que par les entrepreneurs et les innovateurs. Des études approfondies mesurant l'impact des innovations en matière de santé ne seront probablement disponibles que lorsque la pandémie sera davantage maîtrisée et que les experts seront en mesure d'évaluer la répétabilité, la viabilité et l'évolutivité des innovations introduites dans ce domaine.

$$
\begin{aligned}
& \text { توصيف الابتكار ات الصحية خلال الاستجابة لجائحة كوفيد-19 في شرق المتوسط وبلدان عربية خختارة } \\
& \text { أحمد منديل، روث ميبري، باربرا ميلاني، محمد نور، محمد عفيفي، كريم عبد الغني }
\end{aligned}
$$

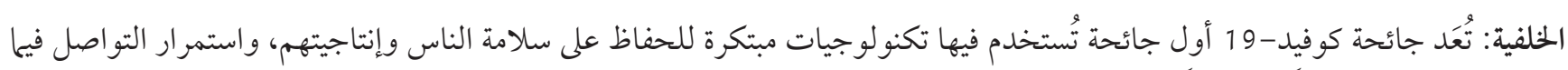
بينهم وهم متباعدون بدنيًّا واجتماعيًّا. الأهداف: هدفت هذه الدراسة إلى توصيف الابتكار ات الصحية التي وُظِّفت خلال الاستِّابة للجائحة في إقليم شرق المتوسط.

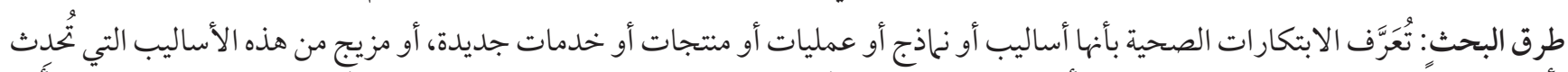

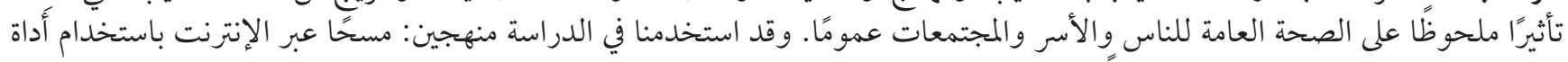

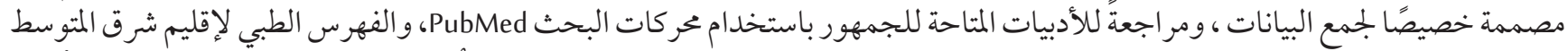

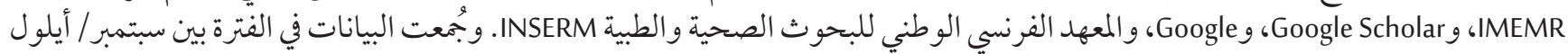
2021 2020 2020

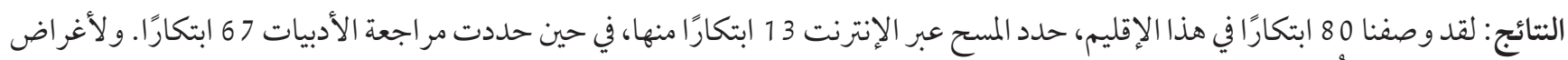

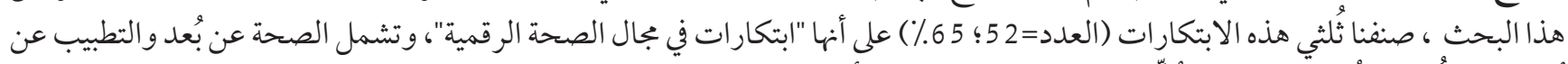

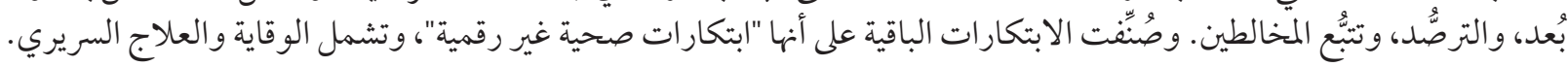

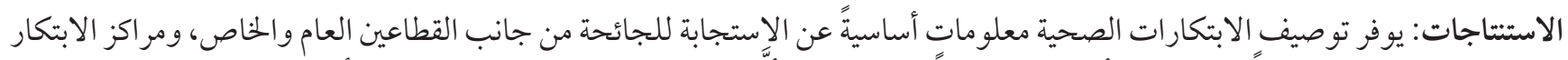

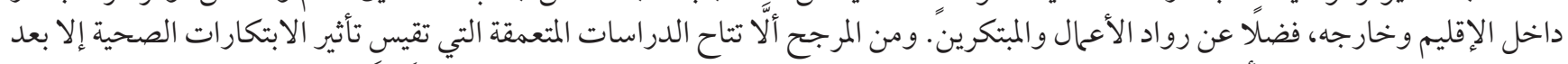

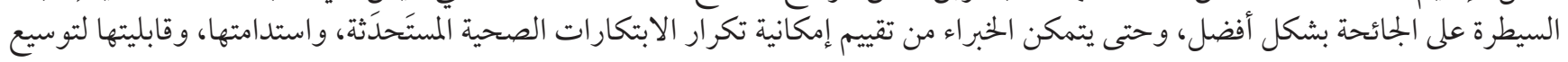




\section{References}

1. Bokolo, A. J. Application of telemedicine and eHealth technology for clinical services in response to COVID-19 pandemic. Health and Technology 2021, 11 (2), 359-366. doi: 10.1007/s12553-020-00516-4.

2. Budd, J., Miller, B. S., Manning, E. M., Lampos, V., Zhuang, M., Edelstein, M., et al. Digital technologies in the public-health response to COVID-19. Nature medicine 2020, 26 (8), 1183-1192. doi: https://doi.org/10.1038/s41591-020-1011-4.

3. He, W., Zhang, Z. J., Li, W. Information technology solutions, challenges, and suggestions for tackling the COVID-19 pandemic. Int J Inf Manage 2021, 57, 102287-102287. doi: 10.1016/j.ijinfomgt.2020.102287.

4. Monaghesh, E., Hajizadeh, A. The role of telehealth during COVID-19 outbreak: a systematic review based on current evidence. BMC Public Health 2020, 20 (1), 1-9. doi: https://doi.org/10.1186/s12889-020-09301-4.

5. Al-Mandhari, A. S., Brennan, R. J., Abubakar, A., Hajjeh, R. Tackling COVID-19 in the Eastern Mediterranean Region. The Lancet 2020, 396 (10265), 1786-1788. doi: 10.1016/So140-6736(20)32349-7.

6. Mowafi, H., Sakr, H., Ravaghi, H., Elmahal, O., Slama, S., Samhouri, D., et al. Leveraging the COVID-19 response to improve emergency care systems in the Eastern Mediterranean Region. Eastern Mediterranean Health Journal 2020, 26 (6), 626-629. doi: 10.26719/2020.26.6.626.

7. Hassounah, M., Raheel, H., Alhefzi, M. Digital response during the COVID-19 pandemic in Saudi Arabia. Journal of Medical Internet Research 2020, 22 (9), e19338. doi: 10.2196/19338.

8. Rawaf, S., Allen, L. N., Stigler, F. L., Kringos, D. Quezada Yamamoto, H.; van Weel, C., et al. Lessons on the COVID-19 pandemic, for and by primary care professionals worldwide. European Journal of General Practice 2020, 26 (1), 129-133. doi: 10.1080/13814788.2020.1820479.

9. World Health Organization, Stronger Collaboration Better Health, Global Action Plan on Healthy Lives and Well-being for all. Geneva: World Health Organization, 2019.

10. World Health Organization. The Regional Health Alliance: A partnership towards achieving Health For All By All. Cairo: World Health Organization, 15 December 2020. http://www.emro.who.int/media/news/the-regional-health-alliance-a-partnership-towards-achieving-health-for-all-by-all.html.

11. Ministry of National Health Services, Regulations and Coordination. Yaran e Watan Yaran e watan. Emergency response for COVID-19. Pakistan, https://yaranewatan.gov.pk/why-yaran-e-watan.

12. Teleheal, A. Arian. Arian Teleheal enables local doctors in warzones and low resource countries to consult with expert clinicians from across the world by using everyday technology such as smartphones, instant messaging and video chat. Afghnistan, https://arianteleheal.com/.

13. National News Agency. Minister of Health discusses twinning mechanism between private, government hospitals to train medical staff to treat Coronavirus patients. Ministry of Information. Beirut: Lebanon, 2020.

14. Bintliff, D., El-Malak, L. COVID-19: Opportunity \& Innovation in the Technology Sector in times of Crisis - A Middle East Perspective. Bird\&Bird 2020.

15. Utilization Review Accreditation Commission Ain Shams University Virtual Hospital Becomes URAC's First International Telehealth Customer. https://www.urac.org/blog/ain-shams-university-virtual-hospital-becomes-uracs-first-international-teles health-customer/.

16. University of Oslo DHIS2. www.dhis2.org/covid-19

17. Mahammedi, N. A.; Mahammedi, A., Standalone solar-powered ultraviolet mobile disinfectant: Bringing solar energy in the global fight against COVID-19. 2020. doi:

18. Hafid, T., "Ozocab", the anti-coronavirus capsule made in Algeria. Sputnik France 12 June 2020, 2020.

19. News, F., Covid-19: Prime Tech is developing a 100\% Moroccan disinfection cabin. Finance News 15 April $2020,2020$.

20. France24, Entrepreneur creates machines "made in Gaza” against coronavirus. France24 29 October 2020, 2020.

21. European External Action Service, EU-funded ShamalStart project teams up with Crown Prince Foundation initiative Techworks for quick and creative ways to address COVID crisis. 2020.

22. Assaf, C., Diving masks converted for medical use. L'Orient-Le Jour 2 April 2020, 2020.

23. World Health Organization, Solar-powered medical oxygen systems saving lives in Somalia: using innovation to accelerate impact in a fragile setting. World Health Organization: Somalia, 2021.

24. Al Quds University The Palestinian Standards Institution and the Ministry of Health approve AQU's medical ventilator. https://www.alquds.edu/en/staff-news/143922-the-palestinian-standards-institution-and-the-ministry-of-health-apt prove-aqu\%E2\%80\%99s-medical-ventilator.html.

25. The Islamic University - Gaza A Response To COVID19: New Ventilator Made At IUG. https://www.iugaza.edu.ps/en/About-IUG/ News/Details/id/28267 (accessed 24 April 2021).

26. Challenge, Coronavirus: the first 100\% Moroccan automatic ventilator is born. Challenge.ma 3 April 2020, 2020.

27. United Nations Office for the Coordination of Humanitarian Affairs (OCHA) Young Somali man invents a home-made ventilator. Humanitarian Bulletin, Somalia 2020, (1-30 June 2020). doi: 
28. Braithwaite, J., Mannion, R., Matsuyama, Y., Shekelle, P. G., Whittaker, S., Al-Adawi, S., et al. The future of health systems to 2030: a roadmap for global progress and sustainability. International Journal for Quality in Health Care 2018, 30 (10), 823-831. doi:

29. Serbulova, N., Morgunova, T. Persiyanova, G. In Innovations during COVID-19 pandemic: trends, technologies, prospects, E3S Web of Conferences, EDP Sciences: 2020; p 02005.

30. World Health Organization, Responding to the COVID-19 pandemic: WHO's action in countries, territories and areas, 2020.2021. doi:

31. World Health Organization, R. O. f. t. E. M., EWARN systems in EMR responding to COVID-19 Pandemic. Weekly Epidemiological Monitor 2020, 13 (15). doi:

32. El Hayek, S., Nofal, M., Abdelrahman, D., Adra, A., Al Harthi, M., Al Shamli, S., et al. Telepsychiatry in the Arab World: A Viewpoint Before and During COVID-19. Neuropsychiatr Dis Treat 2020, 16, 2805-2815. doi: 10.2147/NDT.S277224

33. Helou, S., El Helou, E., Abou-Khalil, V., Wakim, J., El Helou, J., Daher, A., et al. The effect of the COVID-19 pandemic on physicians' use and perception of telehealth: The case of Lebanon. International journal of environmental research and public health 2020 , 17 (13), 4866. doi:

34. Al Hasani, S., Al Ghafri, T., Al Lawati, H., Mohammed, J., Al Mukhainai, A., Al Ajmi, F., et al. The Use of Telephone Consultation in Primary Health Care During COVID-19 Pandemic, Oman: Perceptions from Physicians. Journal of Primary Care \& Community Health 2020, 11, 2150132720976480. doi:

35. United Nations Development Programme, UNDP supports the National Health Hackathon for local health care tech-solutions for communicable diseases including COVID-19. 2020.

36. United Nations Development Programme, COVID-19: An opportunity to develop the Algerian Ecosystem. 2020.

37. Gaza Sky Geeks Hack the crisis palestine, April 15-18, 2020. https://gazaskygeeks.com/hack-the-crisis-palestine/ (accessed 19 April 2021).

38. World Health Organization Ethical considerations to guide the use of digital proximity tracking technologies for COVID-19 contact tracing: interim guidance, 28 May 2020; World Health Organization: 2020.

39. Hassan, A., Mari, Z., Gatto, E. M., Cardozo, A., Youn, J., Okubadejo, N., et al. Global survey on telemedicine utilization for movement disorders during the COVID-19 pandemic. Movement Disorders 2020, 35 (10), 1701-1711. doi:

40. Etabib Etabib. https://etabib.dz/.

41. Ministry of Health Bahrain e-Services Portal, Ministry of Health, Bahrain.

42. Ain Shams University Ain Shams University electronic clinics.

43. Altibbi Altibbi. https://altibbi.com/.

44. Harris Healthcare, Al Amiri Hospital leading the path in Kuwait to digital transformation through its implementation of Harris Healthcare's software. Harris Healthcare: 2020.

45. American University Beirut Medical Center, Healthcare just got closer, your guide to telehealth at AUBMC. Center, A. U. B. M., Ed. American University Beirut Medical Center: Beirut, Lebanon, 2020.

46. Speetar Speetar. https://speetar.com/landing.

47. Ministry of Health Morocco Tbib24. https://tbib24.com/.

48. KIMS Oman Hospital KIMS Oman Hospital, TeleHealth. https://www.kimsoman.com/telehealth

49. Al Nasseri, Z. Virtual clinics to diagnose patients in hospitals. Oman Observer 14 April 2020, 2020.

50. Hamdy, I., Oman Insurance members staying home get access to doctors using TruDoc 24×7. TruDoc 24X7: Dubai, UAE, 2020.

51. Government of Pakistan COVID-19. https://covid.gov.pk/covidı.

52. Ministry of Public Health Qatar, Qatar launching new remote healthcare services . Ministry of Public Health, Qatar: Qatar, 2020.

53. Ministry of Health Saudi Arabia COVID-19. https://covid19awareness.sa/en/apps-for-your-health-2\#

54. Abid, A. Saudi Arabia's Mawid smartphone app offers coronavirus self-assessment. Arab News 3 April 2020, 2020.

55. Hamdy, I. TruDoc $24 \times 7$ DHA licensed doctors provide convenient and round-the-clock teleconsultations to help ease panic surrounding COVID-19. 2020.

56. Zawya, Aster Hospitals introduce virtual outpatient service through teleconsultation. Zawya: 2020.

57. Government of United Arab Emirates Virtual Doctor for COVID-19.

58. Dubai Health Authority, Abu Dhabi further strengthened response to COVID-19 through Malaffi. 2020.

59. World Health Organization, R. O.f. t. E. M. eWARN. http://www.emro.who.int/health-topics/ewarn/index.html.

60. World Health Organization, Oman launches technological surveillance system to track COVID-19. Geneva, Switzerland, 2020.

61. African Heroes, Algeria's Ministry of Startups launches mobilea app to limit coronavirus spread. African Heroes 2020. https:// afrikanheroes.com/2020/03/22/algeria-s-ministry-of-startups-launches-mobile-app-to-limit-coronavirus-spread/

62. COVID-19 Jotech Community About Aman. https://amanapp.jo/en/page/8/AboutAman. 
63. Ministry of Public Health Lebanon “Mazan” Together Against Corona. https://moph.gov.lb/en/mazan\#/en/Pages/6/40882/ mazan.

64. The New Arab, Tunisia launches virus-tracking app. The New Arab 19 May 2020, 2020.

65. Stop Pneumonia. How Somalia used WHO's COVID-19 Biomedical Equipment Inventory Tool to increase oxygen access. Pneumonia, S., Ed. 2020.

66. Thierry, B., Célérier, C., Simon, F., Lacroix, C., Khonsari, RH. How and why use the EasyBreath ${ }^{\circledR}$ surface snorkeling mask as a personal protective equipment during the COVID-19 pandemic? European Annals of Otorhinolaryngology, Head and Neck Diseases 2020, 137 (4), 329-331. 